\title{
Possible function and some properties of the CcpA protein of Bacillus subtilis
}

\author{
Yasuhiko Miwa, Mitsuyuki Saikawa and Yasutaro Fujita
}

Author for correspondence: Y. Fujita. Tel: +8184936 2111. Fax: +81849362023.

Department of Biotechnology, Faculty of Engineering, Fukuyama University, Fukuyama 729 02, Japan

\begin{abstract}
The ccpA mutations alsA1 (alsA1 is allelic to ccpA) and ccpA::Tn917 completely abolished catabolite repression of gluconate kinase and sorbitol dehydrogenase synthesis in Bacillus subtilis, whereas they only partially affected the catabolite repression of inositol dehydrogenase, histidase and xylose isomerase synthesis. The alsA1 mutation also partially affected catabolite repression of sporulation. Analysis of revertants from the alsA1 mutant by direct sequencing indicated that this mutation comprises a base substitution of guanine at nucleotide -14 to adenine within the Shine-Dalgarno sequence of the $\operatorname{ccpA}$ gene (ccpA translation starts at nucleotide + 1). A $1.37 \mathrm{~kb}$ EcoRI fragment carrying the ccpA gene was cloned into Escherichia coli plasmid pUC19 and B. subtilis plasmid pUB110, resulting in plasmids pCCPA19 and pCCPA110, respectively. The ccpA gene carried in pCCPA110 complemented the alsA1 mutation. Western blotting revealed that the level of the CcpA protein in B. subtilis cells, which seemed to be constitutively synthesized, was approximately 10 times lower for the alsA1 mutant than for the wild-type. The CcpA protein synthesized by either $E$. coli cells bearing pCCPA19 or B. subtilis cells bearing PCCPA110 was purified to over $90 \%$ homogeneity; the latter cells were grown in the presence of glucose. The molecular mass of the protein purified from $E$. coli was $74 \mathrm{kDa}$, suggesting that this protein exists as a dimer because its subunit molecular mass was $38 \mathrm{kDa}$ as determined by SDS-PAGE. Gel retardation analysis indicated that the purified CcpA protein in both cases did not bind to the cis sequence for catabolite repression of the gnt operon, but it bound non-specifically to DNA.
\end{abstract}

Keywords: catabolite repression, gluconate metabolism, Bacillus subtilis, CcpA protein

\section{INTRODUCTION}

Several research groups have recently presented interesting findings which imply that Bacillus subtilis might possess a common but unknown negative regulatory mechanism underlying catabolite repression. The five cis sequences responsible for the catabolite repression of the amyE (Nicholson et al., 1987), gnt (Miwa \& Fujita, 1990, 1993), xyl (Jacob et al., 1991), but (Oda et al., 1992) and bglS (Krüger et al., 1993) operons have been determined; these sequences exhibit similarity with the $B$. subtilis catabolite repression consensus sequence, which was originally reported by Weickert \& Chambliss (1990). Moreover, a trans-acting negative gene product (CcpA) which is involved in catabolite repression of the amy $E$ gene was identified (Henkin et al., 1991). The $\operatorname{crs} A 47$ mutation, which is allelic to the $\operatorname{sig} A$ gene encoding the $\sigma^{\mathbf{A}}$ factor of the $B$. subtilis RNA polymerase, affected catabolite repression of the gnt operon, which is mediated by the CcpA protein (Fujita \& Miwa, 1994). The molecular mechanism underlying this negative common catabolite repression is obviously not one involving a cyclic AMP (cAMP) receptor protein-cAMP complex, such as that which has been well demonstrated in enteric bacteria (Botsford \& Harman, 1992). Although the CcpA protein is likely to play a central role in this mechanism (Chambliss, 1993), this new regulation mechanism remains to be elucidated.

In this study, we analysed some properties of an als $A 1$ mutant (als $A 1$ is allelic to $\operatorname{ccp} A$ ) and the purified $\operatorname{CpA}$ protein from Escherichia coli and $B$. subtilis bearing the respective $\operatorname{cs} A$-encoding plasmids. 


\section{METHODS}

Bacterial strains and plasmids. Eschericbia coli strains XL1-blue $\left\{\right.$ sup E44 bsdR $17 \mathrm{rec} A 1$ end $A 1$ gyr $A 46$ thi rel $A 1$ lac $\mathrm{F}^{\prime}\left[\right.$ pro $A B^{+}$ lacI ${ }^{\mathrm{q}}$ lacZ $\left.\left.\Delta \mathrm{M} 15 \mathrm{Tn} 10\left(\mathrm{Tet}^{\mathrm{r}}\right)\right]\right\}$ and JM109 $\{\operatorname{rec} A$ supE44 end $A 1$ bsdR 17 gry $A 96 \operatorname{rel} A 1$ thi $\Delta($ lac-pro $A B) \mathrm{F}^{\prime}\left[\right.$ traD 36 pro $A B^{+}$lac ${ }^{4}$ lacZ $\triangle \mathrm{M} 15]\}$ were used. Bacillus subtilis strains $1 \mathrm{~A} 1$ (trpC2).

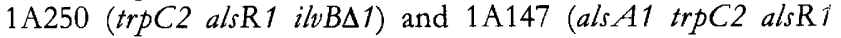
ilvB 1 1) were obtained from the Bacillus Genetic Stock Center: (Ohio State University). B. subtilis strain WLN-29 (aroG932. $\operatorname{trp} C 2 \operatorname{ccp} A:: \operatorname{Tn} 917$ ) was obtained from $\mathrm{G}$. H. Chambliss (Uni-* versity of Wisconsin).

E. coli plasmid pUC19 and B. subtilis plasmid pUB110 were used as vectors for cloning of the $\operatorname{ccp} A$ gene. E. coli plasmid pGNT177 was constructed as described previously (Yoshida $e^{t}$ al., 1993). The $2 \mathrm{~kb}$ EcoRI fragment derived from plasmid pGNT41 (Miwa \& Fujita, 1987) was cloned into the HindII] arm of plasmid pGNT177 after both fragments had been blunt. ended to yield plasmid pGNT61 (Fig. 1b).

Cloning of the $\operatorname{cp} A$ gene. According to the nucleotide sequence of the $\operatorname{ccp} A$ gene reported by Henkin et al. (1991), we prepared a DNA probe [nucleotides +16 to +817 ; translation initiation nucleotide, +1 (Fig. 1a)] for cloning of the $\operatorname{ccp} A$ gene after amplification by means of PCR. EcoRI fragments of DNA. of $B$. subtilis strain $1 \mathrm{~A} 1$ were randomly cloned into pUC19 using $E$. coli strain XL1-blue, and then clones positive on colony hybridization with the above DNA probe were screened. A positive plasmid clone in which the $\operatorname{ccp} A$ gene was cloned in the same orientation as that of lac $Z$ carried in pUC19 was designated as pCCPA19 (Fig. 1b). A $1.37 \mathrm{~kb}$ fragment isolated from an EcoRI digest of plasmid pCCPA19 was ligated with an EcoRI digest of pUB110, and then used for transformation of $B$. subtilis strain 1A147, with respect to kanamycin resistance, to yield plasmid pCCPA110. The sequence of the $1.37 \mathrm{~kb}$ fragment was confirmed by the dideoxy chain-termination method of Sanger: et al. (1977).

Isolation of revertants of the alsA1 mutation. Approximately $10^{5}$ cells of strain $1 \mathrm{~A} 147$ (als $A 1$ trpC 2 als $\mathrm{R} 1$ ilvBA1), obtained from one of single colonies on plates containing tryptose blood agar base (33 $\mathrm{g} \mathrm{l}^{-1}$, Difco) and $10 \mathrm{mM}$ glucose, were inoculated into S6 medium (Fujita \& Freese, 1981) containing $25 \mathrm{mM}$ glucose and $50 \mu \mathrm{g} \mathrm{ml}^{-1}$ each of tryptophan, isoleucine and valine, and allowed to grow overnight at $37^{\circ} \mathrm{C}$. The resulting culture was diluted 1000-fold with the same medium, and allowed to grow for $24 \mathrm{~h}$. This dilution and cultivation were repeated at least six times until cells grew at the same rate as an isogenic wild-type strain, 1A250. Single colonies were isolated from each of 10 independent continuous cultivations. Three revertants out of 10 were tested and confirmed as to retention of the amino acids requirement and restoration of normal catabolite repression of gluconate kinase synthesis; the DNAs of these three revertants were directly sequenced using PCR as described below.

Identification of the base substitution introduced by the alsA1 mutation. The chromosomal regions (nucleotides -279 to +1005 ; the $\operatorname{ccp} A$ structural gene comprises nucleotides +1 to +1002 : Fig. 1) of strains $1 \mathrm{~A} 250$ and $1 \mathrm{~A} 147$, and revertants of strain 1A147, were sequenced directly by means of PCR and cycle sequencing using DNA Sequencer (373A) and Taq Dye Primer Cycle Sequencing Kit (Applied Biosystems), as follows. To prepare the templates for cycle sequencing, this region of their chromosomes was amplified by PCR using four sets of left and right primers containing the $21 \mathrm{M} 13$ and $\mathrm{M} 13$ reverse sequences, respectively. The cycle sequencing of the four templates (approximately $400 \mathrm{bp}$ long) with the $21 \mathrm{M} 13$ and M13 reverse dye primers resulted in four sequences slightly over- (a)

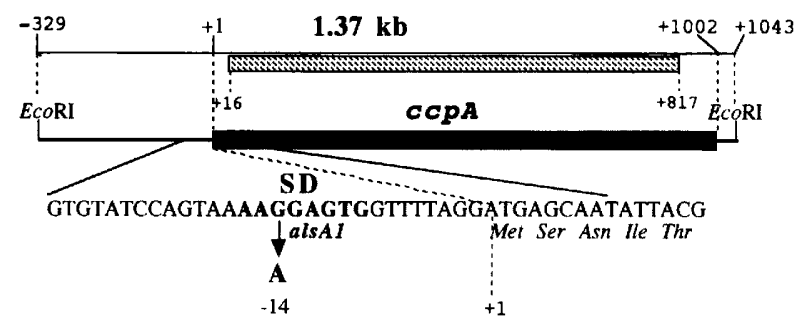

(b)

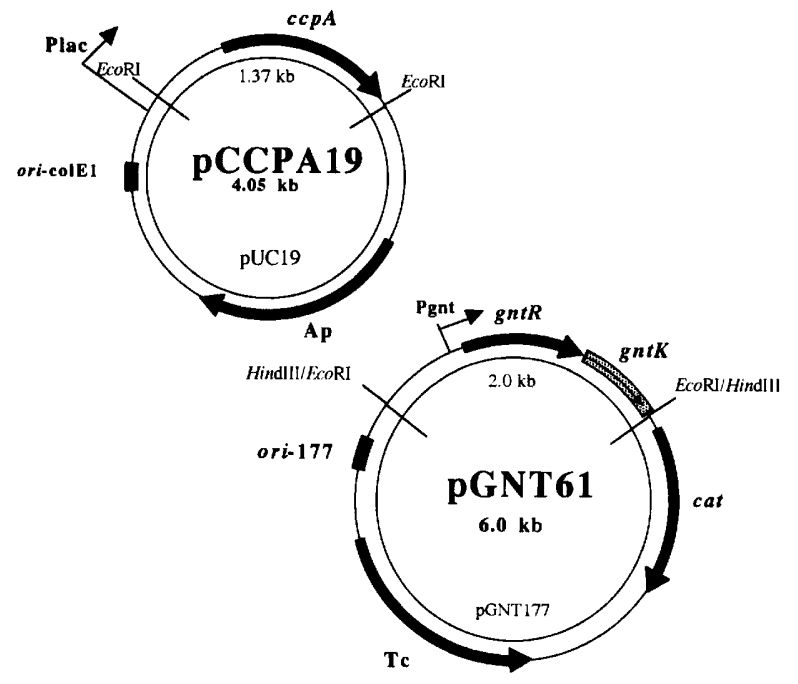

Fig. 1. (a) Location of the a/sA1 mutation. The $1.37 \mathrm{~kb}$ EcoRI fragment carrying the ccpA gene is shown. The initiation codon (ATG) of the ссPA gene was confirmed by determining the $\mathrm{N}$ terminal amino acid of the CcpA protein synthesized by $E$. coli, and its adenine was assigned as nucleotide +1 . As indicated, the alsA1 mutation comprises a guanine substitution with adenine, which is located at nucleotide -14 within the Shine-Dalgarno sequence (SD) for the $\operatorname{ccp} A$ gene. The location of the DNA probe (nucleotides +16 to +817 ) used for cloning of the $\operatorname{ccpA}$ gene is also shown. (b) Structures of the two compatible plasmids, pCCPA19 and pGNT61, used for in vivo analysis of the function of the CCPA protein. pCCPA19 and pGNT61 carry, respectively, the replication origins ori-coliE1 and ori-177, derived from pACYC177 (Chang \& Cohen, 1978). pCCPA19 consists of the ECORI arm of pUC19 and the $1.37 \mathrm{~kb}$ EcoRl fragment carrying the cсpA gene; the orientation of transcription from the lac promoter is the same as that for the ccPA gene. PGNT61 consists of the Hindlll arm of plasmid pGNT177, and a $2.0 \mathrm{~kb}$ EcoRI fragment carrying the gnt promoter and the gntR gene; the cat gene is under the control of the gnt promoter. Ap and TC represent ampicillin and tetracycline resistance genes, respectively.

lapping each other, which were connected to produce the nucleotide sequences corresponding to this region of their chromosomes.

Enzyme assay. For the assay of gluconate kinase, inositol dehydrogenase, histidase, xylose isomerase and sorbitol dehydrogenase, cells were grown at $37^{\circ} \mathrm{C}$ to $\mathrm{OD}_{600} 0.75$ in $\mathrm{S} 6$ medium (Fujita \& Freese, 1981) containing $0.5 \%$ Casamino acids (Difco) and $50 \mu \mathrm{g}$ each of the required amino acids, with or without sodium gluconate $(10 \mathrm{mM})$, myo-inositol $(10 \mathrm{mM})$, histidine $(5 \mathrm{mM})$, xylose $(10 \mathrm{mM})$, and sorbitol $(10 \mathrm{mM})$, and with each of the inducers and $10 \mathrm{mM}$ glucose; for the histidase assay, $43 \mathrm{mM}$ sodium glutamate was added instead of Casamino acids. Cell extracts $\left(9 \mathrm{OD}_{600}\right.$ units $\mathrm{ml}^{-1}$ in $0.1 \mathrm{M}$ Tris $/ \mathrm{HCl}$, 
$\mathrm{pH} 8$ ) were prepared by lysozyme treatment and brief sonication, as described previously (Nihashi \& Fujita, 1984); for the xylose isomerase assay, $0.1 \mathrm{M}$ borate buffer, $\mathrm{pH} 8$, was used. These enzymes were assayed spectrophotometrically by published methods: gluconate kinase and inositol dehydrogenase (Nihashi \& Fujita, 1984), histidase (Chasin \& Magasanik, 1968), xylose isomerase (Horecker, 1974) and sorbitol dehydrogenase (Horwitz \& Kaplan, 1964).

For the CAT assay, cells bearing two compatible plasmids were grown to $\mathrm{OD}_{600} 0.6$ in Luria-Bertani medium containing ampicillin $\left(50 \mu \mathrm{g} \mathrm{ml}^{-1}\right)$, tetracycline $\left(10 \mu \mathrm{g} \mathrm{ml}^{-1}\right)$ and chloramphenicol $\left(10 \mu \mathrm{g} \mathrm{m}^{-1}\right)$, with or without $10 \mathrm{mM}$ gluconate, and with $10 \mathrm{mM}$ each of gluconate and glucose. The cells were harvested and lysed by lysozyme treatment and brief sonication $\left(8 \mathrm{OD}_{600}\right.$ units of cells $\mathrm{ml}^{-1}$ ) as described previously (Yoshida et al., 1993). CAT was assayed spectrophotometrically as described by Shaw (1975).

Purification of the CcpA protein. The CcpA protein synthesized by $E$. coli strain XL1-blue bearing plasmid pCCPA19 was obtained as a $38 \mathrm{kDa}$ polypeptide band on SDS-PAGE (Laemmli, 1970) during purification. Cells grown to the early stationary phase $\left(\mathrm{OD}_{600} 3\right)$ in $300 \mathrm{ml}$ Luria-Bertani medium containing ampicillin $\left(50 \mu \mathrm{g} \mathrm{m}^{-1}\right)$ were disrupted by sonication, and then the CcpA protein was partially purified by essentially the same procedures as those used for the $B$. subtilis $\mathrm{G}$ tR $\mathrm{R}$ protein (Miwa \& Fujita, 1988) (60\% ammonium sulfate precipitation, and subsequent column chromatographies on Bio-Gel A-1.5 m and DEAE-cellulose, but without the phosphocellulose column chromatography). After the DEAE-cellulose chromatography, an aliquot of the CcpA preparation ( $40 \mathrm{mg}$ total protein) in $20 \mathrm{mM}$ Tris $/ \mathrm{HCl}$ buffer, $\mathrm{pH} 7.9$, containing $0.05 \mathrm{M} \mathrm{KCl}$, $0.1 \mathrm{mM}$ NaEDTA, pH $8,0.1 \mathrm{mM}$ dithiothreitol, $1 \mathrm{mM}$ phenylmethylsulfonyl fluoride and $20 \%(\mathrm{v} / \mathrm{v})$ glycerol, was applied to a calf thymus DNA-cellulose column $(1.6 \times 4.0 \mathrm{~cm})$ prepared in the same buffer. The column was washed with $100 \mathrm{ml}$ of the buffer and then eluted with a $100 \mathrm{ml}$ linear $\mathrm{KCl}$ gradient $(0.05-0.3 \mathrm{M})$. Fractions $(0.9 \mathrm{ml})$ containing the CcpA protein (eluted at around $0 \cdot 125 \mathrm{M} \mathrm{KCl}$ ) were pooled, concentrated and dialysed against the buffer without $\mathrm{KCl}$ in a Collodion bag (Sartorius) to give $1 \mathrm{mg} \mathrm{CcpA} \mathrm{protein.}$

The CcpA protein synthesized by B. subtilis strain 1 A250 bearing pCCPA110 was purified by the same procedures as described above. Cells were grown to $\mathrm{OD}_{600} 0.75$ in 3 litres of $\mathrm{S} 6$ medium containing $0.5 \%$ Casamino acids, $50 \mu \mathrm{g} \mathrm{m} \mathrm{m}^{-1}$ each of the required amino acids, $5 \mu \mathrm{g}$ kanamycin $\mathrm{ml}^{-1}$, and $10 \mathrm{mM}$ each of gluconate and glucose. During CcpA purification, yielding $28 \mu \mathrm{g}$ protein, this protein was pursued by Western blotting. After SDS-PAGE (10\%, w/v, gel) and blotting, immunological detection was performed using rabbit antiserum against the Ccp A protein purified from $E$. coli cells and then anti-rabbit IgG horseradish peroxidase conjugate (Bio-Rad). This rabbit antiserum was generated as described previously (Fujita \& Freese, 1981).

Characterization of the CcpA protein. The molecular mass of the CcpA protein was determined by gel filtration on a Sephacryl S-300 column (Pharmacia, $0.5 \times 115 \mathrm{~cm}$ ) with molecular mass markers of thyroglobulin ( $669 \mathrm{kDa})$, catalase $(232 \mathrm{kDa})$, gamma globulin $(158 \mathrm{kDa})$, bovine serum albumin $(67 \mathrm{kDa})$, ovalbumin $(44 \mathrm{kDa})$, myoglobin $(17 \mathrm{kDa})$, ribonuclease $\mathrm{A}(13.7 \mathrm{kDa})$ and cyanocobalamin $(1.35 \mathrm{kDa})$.

For determination of the $\mathrm{N}$-terminal amino acid sequence of the CcpA protein, the purified protein was electrophoresed on a $10 \%$ SDS-polyacrylamide gel, and then this protein on the gel was blotted onto a PVDF protein sequencing membrane (BioRad) using Bio-Rad Trans-blot SD according to the instruction manual. After deformylation of the CcpA protein (approxi- mately $3 \mu \mathrm{g}$ ) on the membrane in $0.6 \mathrm{M} \mathrm{HCl}$ at $25^{\circ} \mathrm{C}$ for $24 \mathrm{~h}$, it was washed with distilled water, dried and then applied to a protein sequencer (PPSQ-10, Shimadzu, Kyoto).

Gel retardation analysis of DNA binding of the CcpA protein was performed as described previously (Yoshida et al., 1993). Three DNA fragments were isolated from an $\mathrm{HpaII}$ digest of a 742 bp HindIII fragment containing the gnt promoter (nucleotides -202 to +541 ; gnt transcription initiation base, +1) (Fujita \& Fujita, 1986), labelled with $\left[\alpha_{-}^{32} \mathrm{P}\right] \mathrm{dCTP}$ (Amersham) by means of the filling-in reaction, and then added to the binding reaction mixture; these three fragments, of 291, 113 and $338 \mathrm{bp}$, carried gnt sequences of -202 to $+90,+91$ to +203 , and +204 to +541 , respectively.

\section{RESULTS}

\section{Effect of the ccpA mutations on catabolite repression of adaptive enzyme syntheses and sporulation}

Table 1 shows that the als $A 1$ mutation, which is allelic to $\operatorname{ccp} A$, and the $\operatorname{ccp} A:: \operatorname{Tn} 917$ mutation (Zahler et al., 1990; Henkin $e t$ al., 1991) affected not only catabolite repression of the synthesis of gluconate kinase, but also that of the synthesis of inositol dehydrogenase, histidase, xylose isomerase and sorbitol dehydrogenase. Although the catabolite repression of synthesis of gluconate kinase and sorbitol dehydrogenase was completely abolished by these two $\operatorname{ccp} A$ mutations, that of the synthesis of inositol dehydrogenase, histidase and xylose isomerase was only partially affected by them, suggesting that catabolite repression(s) not involving the CcpA protein as well as that mediated by this protein might operate in the latter three enzyme syntheses.

As shown in Table 2, the als $A 1$ mutation also affected sporulation, but the effect was observed only when catabolite repression of sporulation of strain $1 \mathrm{~A} 147$ was compared with that of strain 1A250; strain 1A147 could sporulate efficiently even in the presence of $0.8 \%$ glucose, whereas strain $1 \mathrm{~A} 250$ could not sporulate normally in the presence of $0.5 \%$ glucose. We did not have an isogenic strain of strain WLN-29, so it was difficult to judge whether the $\operatorname{ccp} A:: \operatorname{Tn} 917$ mutation affected sporulation. Thus, the CcpA protein was considered to be only partially involved in catabolite repression of sporulation. The finding that the CcpA protein was involved in catabolite repression of not only adaptive enzyme syntheses but also sporulation implies that an unknown mechanism involving this protein may play a central role in B. subtilis catabolite repression.

\section{Identification of the base substitution present in the alsA1 mutation}

Since the als $A 1$ mutation is a very stable $c c p A$ mutation, and strain $1 \mathrm{~A} 147$ carrying this mutation has a good isogenic strain (1A250), we attempted to identify the base substitution introduced in the als $A 1$ mutation. According to the nucleotide sequence of the $1.37 \mathrm{~kb}$ EcoRI fragment containing the $\operatorname{csp} A$ gene (Henkin et al., 1991), we designed and synthesized several primers for PCR amplification using DNAs of strains $1 \mathrm{~A} 250$ and $1 \mathrm{~A} 147$; this amplification could cover the region from nucleotide -279 to +1005 (translation of $\operatorname{ccp} A$ starts at +1 : Fig. 1 a) 
Table 1. Effect of the ccpA::Tn917 and alsA1 mutations on catabolite repression of synthesis of gluconate kinase, inositol dehydrogenase, histidase, xylose isomerase and sorbitol dehydrogenase

Cell growth, preparation of the crude extracts and assaying of the enzymes are described in the text. The experiments were each performed three times. Representative results are shown.

\begin{tabular}{|c|c|c|c|c|c|}
\hline \multirow[t]{2}{*}{ Strain } & \multicolumn{5}{|c|}{$\begin{array}{l}\text { Repression ratio of enzyme activity without glucose to that with } \\
\text { glucose }\end{array}$} \\
\hline & $\begin{array}{l}\text { Gluconate } \\
\text { kinase }\end{array}$ & $\begin{array}{l}\text { Inositol } \\
\text { dehydrogenase }\end{array}$ & Histidase & $\begin{array}{c}\text { Xylose } \\
\text { isomerase }\end{array}$ & $\begin{array}{l}\text { Sorbitol } \\
\text { dehydrogenase }\end{array}$ \\
\hline $1 \mathrm{~A} 250\left(\operatorname{ccp} A^{+}\right)$ & $>27$ & $>317$ & $>34$ & $>26$ & $8 \cdot 4$ \\
\hline $1 \mathrm{~A} 147$ (als $A 1)$ & $0 \cdot 8$ & $4 \cdot 9$ & $2 \cdot 6$ & $10 \cdot 5$ & $1 \cdot 0$ \\
\hline WLN-29 (ccpA:: Tn917) & $1 \cdot 0$ & $1 \cdot 8$ & $1 \cdot 5$ & $13 \cdot 9$ & $1 \cdot 0$ \\
\hline
\end{tabular}

\section{Table 2. Effect of the alsA1 mutation on catabolite repression of sporulation}

Cells were allowed to sporulate in nutrient sporulation medium (Fujita \& Freese, 1981) at $37^{\circ} \mathrm{C}$ for $24 \mathrm{~h}$. For titration of spores, the cultures were treated at $75^{\circ} \mathrm{C}$ for $15 \mathrm{~min}$. The experiments were repeated at least twice; representative results are shown. Sporulation percentage is defined as [(no. of spores)/(no. of viable cells) $] \times 100$.

\begin{tabular}{|lrrrrr|}
\hline \multirow{2}{*}{ Strain } & \multicolumn{5}{c|}{ Sporulation percentage } \\
\cline { 2 - 6 } & \multicolumn{5}{c|}{ Glucose concn (\%): } \\
& $\mathbf{0 . 2}$ & $\mathbf{0 . 5}$ & $\mathbf{0 . 8}$ & $\mathbf{1 . 2}$ & $\mathbf{2 . 0}$ \\
\hline 1A250 (ccp $\left.A^{+}\right)$ & 90.0 & 3.1 & 0.9 & 0.6 & 0.7 \\
1A147 (als $A 1)$ & 77.0 & 71.0 & 20.0 & 2.0 & 1.3 \\
\hline
\end{tabular}

containing the putative $\operatorname{csp} A$ promoter and its structural gene, encoding 334 amino acids. Cycle sequencing of the DNA fragments amplified with DNA of strain 1A250 revealed that the sequence determined with DNA of strain 1A250 completely coincided with the reported sequence of this region. However, we detected one mismatch with DNA of strain 1A147, namely a base substitution of guanine at nucleotide -14 to adenine within the Shine-Dalgarno sequence for the $\operatorname{ccp} A$ gene, indicating that the als $A 1$ mutation might be due to this base substitution (Fig. 1a).

Strain 1A147 grew more slowly in S6 medium containing glucose as the sole carbon source than did strain 1A250; their doubling times were $2 \cdot 2$ and $1.6 \mathrm{~h}$, respectively. We isolated 10 independent revertants of strain 1 A147 which grew at the same rate as 1 A250 after successive cultivations under these growth conditions. Three of these revertants were examined as to catabolite repression of gluconate kinase synthesis, and all of them exhibited normal catabolite repression (data not shown). The base substitutions which had occurred in the DNA of these strains were identified by means of DNA amplification and cycle sequencing; all were found to be reversion of adenine to guanine at nucleotide -14 , so we concluded that the als $A 1$ mutation does indeed comprise adenine substitution of guanine at nucleotide -14 within the Shine-Dalgarno sequence for the $\operatorname{ccp} A$ gene.

\section{Cloning and expression of the ccpA gene in $E$. coli and $B$. subtilis plasmids, and purification of the CcpA protein}

The $1.37 \mathrm{~kb}$ EcoRI fragment containing the $\operatorname{ccp} A$ gene was cloned into $E$. coli plasmid pUC19 to produce $E$. coli strain XL1-blue bearing pCCPA19 by means of colony hybridization using a PCR-amplified fragment (nucleotides +16 to +817 ) as a probe (Fig. 1). The $1.37 \mathrm{~kb}$ fragment derived from pCCPA19 was also cloned into $B$. subtilis plasmid pUB110 to produce strains $1 \mathrm{~A} 147$ and 1 A250 bearing plasmid pCCPA110. Table 3 shows that normal catabolite repression of gluconate kinase synthesis was observed in strain 1A147 bearing pCCPA110, but not in strain 1A147 bearing pUB110, indicating that the $\operatorname{ccp} A$ gene in the $1.37 \mathrm{~kb}$ fragment cloned into pUB110 complemented the als $A 1$ mutation; the $\operatorname{ccp} A$ gene cloned in $\mathrm{SP} \beta$ prophage was also reported to complement this mutation (Henkin et al., 1991). However, the overproduced CcpA protein seemed to be somewhat harmful to $B$. subtilis cells, because the induction of gluconate kinase (Table 3) and the growth rate (data not shown) were affected by the presence of pCCPA110 in either strain $1 \mathrm{~A} 250$ or $1 \mathrm{~A} 147 ; 1 \mathrm{~A} 250$ and $1 \mathrm{~A} 147$ cells bearing pCCPA110 grew at approximately two-thirds the rates of the respective strains bearing pUB110.

E. coli strain XL1-blue bearing pCCPA19 could constitutively synthesize a protein, which accounted for approximately $5 \%$ of the total protein, that had the electrophoretic mobility of a polypeptide of approximately $38 \mathrm{kDa}$ on SDS-PAGE; strain XL1-blue bearing pUC19 did not synthesize the protein. This putative CcpA protein was purified to approximately $95 \%$ homogeneity, as shown in Fig. 2. The N-terminal sequence of the purified protein was determined with an automatic sequencer after the protein had been deformylated. This deformylation enhanced the yield of each hydrolysed residue by approximately 1.4-fold, suggesting that the first methionine might be partially formylated. Although the $\mathrm{N}$-terminal meth- 
Table 3. Complementation of the chromosomal alsA1 mutation with pCCPA110 (ccp $\left.A^{+}\right)$

Cell growth, preparation of the crude extracts and assaying of gluconate kinase are described in the text. Representative results from three independent experiments are shown. Gnt, gluconate; Glc, glucose.

\begin{tabular}{|c|c|c|c|c|c|}
\hline \multirow[t]{2}{*}{ Strain } & \multirow[t]{2}{*}{ Plasmid } & \multicolumn{3}{|c|}{ Gluconate kinase ( $\mathrm{nmol} \mathrm{min}^{-1} \mathrm{mg}^{-1}$ ) } & \multirow{2}{*}{$\begin{array}{l}\text { Repression ratio } \\
\text { (Gnt/Gnt + Glc) }\end{array}$} \\
\hline & & No Gnt & Gnt & Gnt + Glc & \\
\hline \multirow{2}{*}{$1 \mathrm{~A} 250\left(\operatorname{ccp} A^{+}\right)$} & pUB110 & $<1 \cdot 0$ & $44 \cdot 8$ & $<1 \cdot 0$ & $>44$ \\
\hline & pCCPA110 & $<1 \cdot 0$ & $32 \cdot 6$ & $<1 \cdot 0$ & $>32$ \\
\hline \multirow[t]{2}{*}{$1 \mathrm{~A} 147($ als $A 1)$} & pUB110 & $<1.0$ & $52 \cdot 9$ & $49 \cdot 1$ & $1 \cdot 1$ \\
\hline & pCCPA110 & $<1 \cdot 0$ & $34 \cdot 7$ & $<1 \cdot 0$ & $>34$ \\
\hline
\end{tabular}

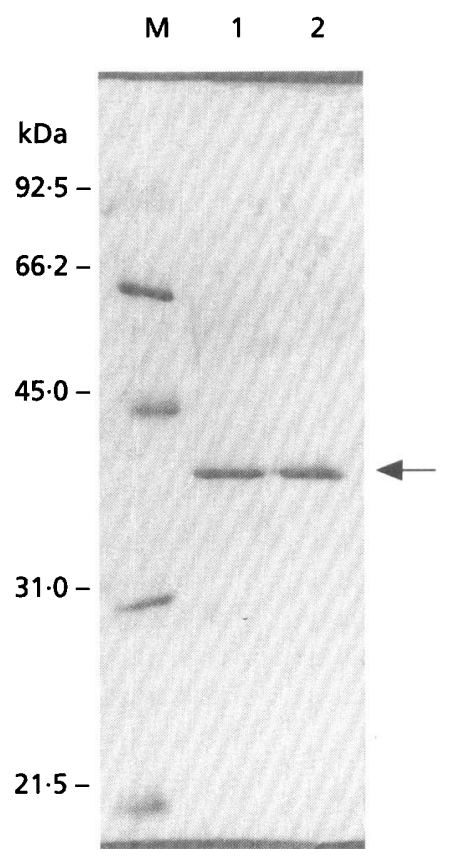

Fig. 2. The CcpA proteins purified from $B$. subtilis and $E$. coli cells. The purified CcpA proteins $(1.5 \mu \mathrm{g}$ each) synthesized by $B$. subtilis strain 1 A250 bearing PCCPA110 (lane 1) and $E$. coli strain XL1-blue bearing PCCPA19 (lane 2) were applied to a $10 \%$ SDS-polyacrylamide gel. Lane $M$ contains standard proteins used as molecular mass markers: phosphorylase $b$ $(92.5 \mathrm{kDa})$, bovine serum albumin $(66.2 \mathrm{kDa})$, ovalbumin $(45.0 \mathrm{kDa})$, carbonic anhydrase $(31.0 \mathrm{kDa})$ and soybean trypsin inhibitor $(21.5 \mathrm{kDa})$. The CcpA protein $(38 \mathrm{kDa})$ is indicated by an arrow.

ionine, which should appear at the first cycle, was scarcely detected, the second to eleventh amino acid terminal residues were the same as reported by Henkin $e t$ al. (1991), indicating that the purified protein was the CcpA protein which had been translated from an initiation codon, ATG, starting from nucleotide +1 (Fig. 1 a). Since we had identified the initiation codon of the $\operatorname{ccp} A$ gene, we could conclude that the als $A 1$ mutation comprises a substitution of guanine to adenine at nucleotide -14 within the Shine-Dalgarno sequence for the $\operatorname{csp} A$ gene (Fig. 1a).

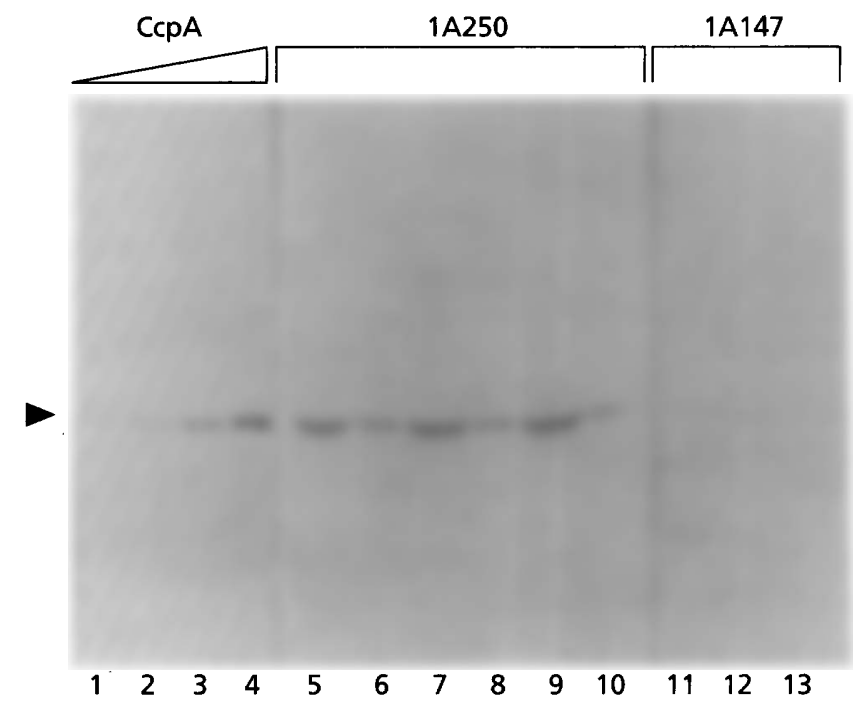

Fig. 3. Western blotting for determination of the CcpA protein levels in B. subtilis cells. Cells were grown in S6 medium containing $50 \mu \mathrm{g}$ each of the required amino acids, with or without $10 \mathrm{mM}$ gluconate or with gluconate and glucose. Cell extracts from $190 O_{600}$ units of cells were prepared by the same method as the first step for purification of the C $\mathrm{cpA}$ protein using sonication; the extracts contained approximately $60 \mathrm{mg}$ total protein $\mathrm{ml}^{-1}$. Western blotting was performed as described in the text. Lanes $1,2,3$ and 4 contained, respectively, 45, 90, 180 and $360 \mathrm{ng}$ CcpA protein purified from $E$. coli. Lanes 5 to 10 and lanes 11 to 13 contained cell extracts from strains 1A250 (wild-type) and 1 A147 (alsA1), respectively. Lanes 5, 7, 9, 11, 12 and 13; and lanes 6, 8 and 10 contained 270 and $90 \mu \mathrm{g}$ of total protein, respectively. Lanes 5,6 and 11 ; lanes 7,8 and 12 ; and lanes 9,10 and 13 contained, respectively, extracts from cells grown without gluconate; with gluconate; and with gluconate and glucose.

The molecular mass of the CcpA protein purified from $E$. coli cells was determined by gel filtration to be $74 \mathrm{kDa}$. The molecular mass of the subunit of the CcpA protein is $38 \mathrm{kDa}$, so the CcpA protein probably exists as a dimer.

The CcpA protein synthesized by B. subtilis strain $1 \mathrm{~A} 250$ bearing pCCPA110 was also purified to over $90 \%$ homogeneity by the same purification procedures as those used for the E. coli cell extract. We purified the CcpA 


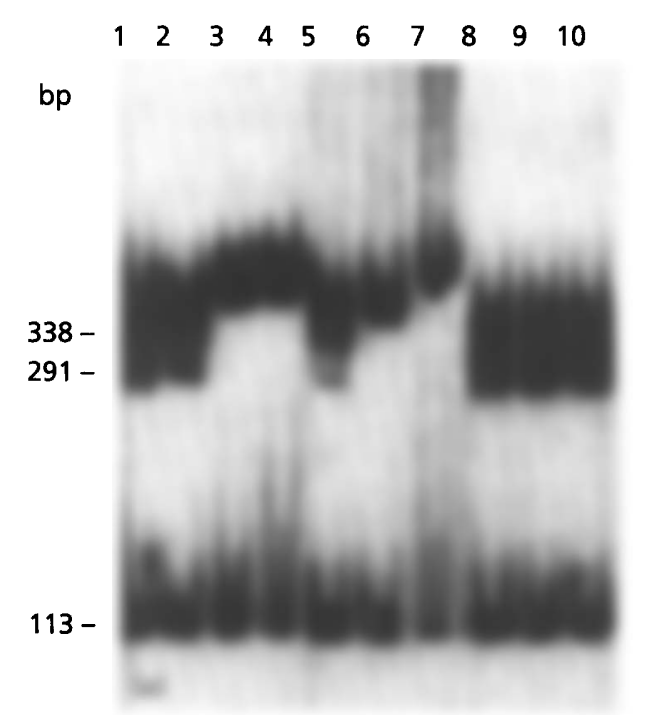

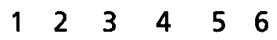

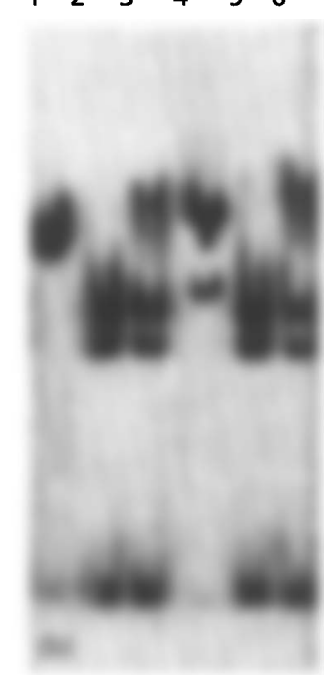

Fig. 4. DNA binding ability of the CcpA protein. Gel retardation analysis for DNA binding of the purified CcpA protein was performed as described previously (Yoshida et al., 1993). Three DNA fragments (113, 291 and $338 \mathrm{bp}$ ) ( $100 \mathrm{pM}$ each) were added to the reaction mixtures; the 291 and $113 \mathrm{bp}$ fragments contain the gnt promoter and the cis sequence for catabolite repression of gnt, respectively, while the 338 bp fragment was an internal control for this analysis. The preparation of these fragments was described in the text. (a) Lane 1 contained no protein; lanes 2 to 4, CcpA protein synthesized by $B$. subtilis; lanes 5 to 7, CcpA protein synthesized by $E$. coli; and lanes 8 to 10 , ovalbumin. The concentrations of the added protein in the binding reaction mixture were as follows: lanes 2, 5 and 8 , $80 \mathrm{nM}$; lanes 3, 6 and 9, $160 \mathrm{nM}$; lanes 4, 7 and $10,320 \mathrm{nM}$. (b) The C CPA proteins $(320 \mathrm{nM})$ purified from $B$. subtilis (lanes 1 to 3) and $E$. coli (lanes 4 to 6 ) were added to the binding mixture. Lanes 1 and 4 contained no competitive DNA; lanes 2 and 5 contained $2.5 \mu \mathrm{g}$ sonicated calf thymus DNA of $500 \mathrm{bp}$ in average length; lanes 3 and 6 contained $100 \mathrm{nM}$ of the $338 \mathrm{bp}$ fragment. protein from an extract of cells grown in the presence of glucose, that is, under conditions exerting catabolite repression. However, we could not distinguish it from that purified from E. coli cell extracts on SDS-PAGE (Fig. 2 ), indicating that no protein modification could be detected by this technique.

\section{CcpA protein levels in cells of strains $1 \mathrm{~A} 250$ and $1 \mathrm{~A} 147$}

Strains $1 \mathrm{~A} 250$ and $1 \mathrm{~A} 147$ were cultivated under three growth conditions: where gluconate kinase was not induced, where it was induced by gluconate, and where this induction was repressed by glucose. The levels of the CcpA proteins in crude extracts of these cells were measured by Western-blotting (Fig. 3). The results indicated that this protein was probably synthesized constitutively under all three growth conditions. Cell extracts of strain $1 \mathrm{~A} 250$ contained approximately $2 \mu \mathrm{g}$ CcpA protein per $\mathrm{mg}$ total protein (Fig. 3), which corresponds to roughly 3000 molecules per cell on the assumption that proteins were completely extracted from the cells. The CcpA level in strain 1A147 (als A1) was approximately 10-fold lower than that in strain 1A250 $\left(\right.$ als $\left.A^{+}\right)$(Fig. 3), probably due to a decrease of CcpA synthesis in this mutant caused by the poor binding of ribosomes to the mutated binding site within the ShineDalgarno sequence for the $c c p A$ gene.

\section{Inability of the CcpA protein to bind to the cis sequence for catabolite repression of the gnt operon}

It has been proven in the systems of amyE, $b g l S$ and $g n t$, which are now known to include $x y l$ and but, that catabolite repression requiring the consensus cis sequence is mediated by the CcpA protein. Furthermore, the CcpA protein could bind non-specifically to DNA-cellulose, suggesting that it might be a DNA-binding protein. Thus, we examined by means of gel retardation analysis whether the purified CcpA protein could bind to the cis sequence for catabolite repression of the gnt operon, which is located downstream of the gnt promoter (Miwa \& Fujita, 1993). In our gel retardation analysis (Fig. 4), $100 \mathrm{pM}$ each of three labelled DNA fragments derived from a 742 bp HindIII fragment (Fujita \& Fujita, 1986) were added; the 113 and $291 \mathrm{bp}$ fragments carry the cis sequence for gnt catabolite repression and the gnt promoter, respectively, while the $338 \mathrm{bp}$ fragment, which was added as an internal control, contains no known specific sequence. Even when the CcpA protein purified from either $B$. subtilis or $E$. coli cells was added in an amount corresponding to 400 times higher molarity than that of the DNA fragments, the mobility of the latter did not change at all (data not shown). When more of this protein was added, the DNA fragments started to shift, as shown in Fig. 4(a): the 291 bp fragment began to shift on the addition of CcpA protein at 800 times higher molarity (lanes 2 and 5), and the $338 \mathrm{bp}$ fragment shifted on the addition of 1600 times higher molarity (lanes 3 and 6); however, the $113 \mathrm{bp}$ fragment did not shift well even on the addition of 3200 times higher molarity (lanes 4 and 7). We do not know the reason why these three fragments exhibited different shifts, though it might be partially due to their sizes. Anyway, these shifts were not observed on the addition of ovalbumin as a control (lanes 8 to 10 , Fig. 4a). When either $100 \mathrm{nM}$ of the unlabelled $338 \mathrm{bp}$ fragment (1000 times molarity compared to that of the three labelled fragments) or $2.5 \mu \mathrm{g}$ of sonicated calf thymus DNA was added to the binding reaction mixture, 
Table 4. CAT synthesis under the control of the gnt promoter in the presence of the ccpA gene in $E$. coli

Cell growth, preparation of the crude extracts and assaying of CAT are described in the text. The amounts of pGNT61 in the crude plasmid preparations were determined densitometrically by agarose gel electrophoresis; then the copy numbers per mg protein in crude extracts were calculated on the assumption that the plasmid yield from the same amount of cells from which the crude extract had been prepared was almost $100 \%$. The experiments were repeated at least twice; representative data are shown. Gnt, gluconate; Glc, glucose.

\begin{tabular}{|c|c|c|c|c|}
\hline \multirow[t]{2}{*}{ Plasmid set in cells } & \multicolumn{3}{|c|}{$\begin{array}{c}\text { CAT activity } \\
\left(\mathrm{nmol} \mathrm{min}^{-1} \text { per } 10^{10} \text { copies of pGNT61) }\right.\end{array}$} & \multirow[t]{2}{*}{$\begin{array}{l}\text { Repression ratio } \\
\text { (Gnt/Gnt + Glc) }\end{array}$} \\
\hline & No Gnt & Gnt & Gnt + Glc & \\
\hline pGNT61, pUC19 & $25 \cdot 1$ & $102 \cdot 3$ & $103 \cdot 2$ & 0.99 \\
\hline pGNT61, pCCPA19 & $20 \cdot 1$ & 143.9 & $174 \cdot 8$ & 0.82 \\
\hline
\end{tabular}

none of the labelled DNA fragments shifted (Fig. 4b). These results clearly indicated that neither the CcpA protein from $E$. coli cells nor that from $B$. subtilis cells grown with glucose binds to the cis sequence for catabolite repression of the gnt operon, but both proteins bind nonspecifically to DNA.

Our observation that the CcpA protein only bound nonspecifically to DNA might be due to artifacts such as inactivation of the $\mathrm{CcpA}$ protein during its purification and/or the conditions for the gel retardation analysis. Thus, we attempted to reconstruct catabolite repression of gnt in E. coli cells by using the cat gene under gnt regulation and the CcpA protein synthesized in vivo. E. coli strain JM109 was transformed with two compatible plasmids, pGNT61 and pUC19 (or pCCPA19), which carry ori-177 and ori-colE1 for their replication, respectively (Fig. 1b); pGNT61 carries the cat gene under the control of the gnt induction system. We have already reported that in $B$. subtilis, the syntheses of CAT and subtilisin under the direction of this gnt promoter construct using the respective promoter-probe plasmids are subject to glucose repression (Fujita \& Fujita, 1987; Miwa \& Fujita, 1990). As shown in Table 4, CAT synthesis was induced in cells bearing plasmids pGNT61 and $\mathrm{pLC} 19$ upon the addition of gluconate to the medium. When pCCPA19 was introduced instead of pUC19, CAT synthesis was not affected by the synthesized CcpA protein even in cells grown with glucose (Table 4). (The CAT activities shown in this table were normalized per $10^{\mathbf{1 0}}$ copies of pGNT61 because the copy number of pGNT61 in cells bearing both pGNT61 and pCCPA19 was decreased in comparison with that in cells bearing pGNT61 and pUC19, which was caused by the expression of the $\operatorname{csp} A$ gene. We do not know why the CcpA protein decreased the copy number of plasmid pGNT61.) The results suggest that the signalling system from extracellular glucose to catabolite repression of the gnt operon mediated by the CcpA protein might not work in E. coli. However, this observation implies that the CcpA protein by itself might not bind to the cis sequence for catabolite repression of the gnt operon, because CAT synthesis under the control of the gnt regulation involving this $c i s$ sequence was not affected negatively by the $\mathrm{CcpA}$ protein in $E$. coli cells.

\section{DISCUSSION}

Catabolite repression mediated by the CcpA protein is likely to be a global regulatory system because the $\operatorname{csp} A$ mutation has pleiotropic effects on catabolite repression of various adaptive enzyme syntheses. This protein was found to be involved not only in catabolite repression of $\alpha$-amylase synthesis (Henkin et al., 1991), but also in that of levanase (Martin et al., 1989), $\beta$-glucanase (Krüger et al., 1993) and gluconate kinase (Fujita \& Miwa, 1994) syntheses. In addition the $\operatorname{ccp} A$ mutations affected the catabolite repression of inositol dehydrogenase, histidase, xylose isomerase and sorbitol dehydrogenase syntheses, as well as that of sporulation (Tables 1 and 2). Furthermore, the production of acetoin is abolished by the als $A 1$ mutation (Zahler et al., 1990), and the stimulation of ack $A$ expression by glucose was blocked in a $\operatorname{ccp} A$ mutant (Grundy et al., 1993). These observations suggest that the $\operatorname{ccp} A$ gene plays an important role in coordinating global gene expression in response to rapidly metabolizable carbohydrates in the medium.

It has been reported that catabolite repression of the amy $E$ (Nicholson et al., 1987), gnt (Miwa \& Fujita, 1990, 1993), xyl (Jacob et al., 1991), hut (Oda et al., 1992) and bglS (Krüger et al., 1993) operons involves the respective five cis sequences, which exhibit similarity with the $B$. subtilis catabolite repression consensus sequence (Weickert \& Chambliss, 1990). Among these systems, the CcpA protein has been reported to be involved in catabolite repression of amyE (Henkin et al., 1991), bglS (Krüger et al., 1993) and gnt (Fujita \& Miwa, 1994). In the present study, we showed that this protein was involved in catabolite repression of the but and $x y l$ operons (Table 1). These facts suggest that $B$. subtilis catabolite repression involving the consensus cis sequence seems to be generally mediated by a negative regulator of the CcpA protein. However, the CcpA protein seemed to be synthesized constitutively in B. subtilis cells (Fig. 3). Our gel retardation analysis 
involving the CcpA proteins purified from both $B$. subtilis and $E$. coli indicated that the $C \operatorname{cpA}$ protein was a nonspecific DNA-binding protein (Fig. 4). Not only the CcpA protein purified from $E$. coli cells but also that from $B$. subtilis cells grown under conditions exerting catabolite repression did not bind specifically to the is sequence for catabolite repression of the gnt operon, as judged by gel retardation analysis (Fig. 4). We do not think that the specific binding activity of this protein to the cis sequence was specifically lost during purification because the purified CcpA proteins retained the non-specific binding ability. We could not detect any specific binding ability in protein preparations from any step of our purification procedures (data not shown). Further evidence that the CcpA protein by itself probably does not interact with the cis sequence for $B$. subtilis catabolite repression in $E$. coli cells comes from the observation that this protein did not affect the expression of the cat gene under the control of the gnt induction system (Table 4); it remains a possibility that gnt transcription by $E$. coli RNA polymerase might not be affected even if the CcpA protein bound to the cis sequence for $B$. subtilis catabolite repression.

Although we cannot exclude the possibility that the above results might be due to unexpected artifacts in our in vivo and in vitro experiments, they can be reasonably explained as follows: (i) the CcpA protein is indirectly involved in catabolite repression through regulation of another regulatory gene whose product can recognize the consensus $c i s$ sequence for catabolite repression; or (ii) this protein requires a conformational change in its three-dimensional configuration for specific binding to the consensus cis sequence for $B$. subtilis catabolite repression. This change can be induced by a protein modification such as proteolysis or protein phosphorylation, which could not be detected on SDS-PAGE (Fig. 2), or by association with some factor (protein or metabolite).

\section{ACKNOWLEDGEMENTS}

The authors would like to thank Dr $\mathrm{H}$. Iwamoto for help with $\mathrm{N}$-terminal amino acid sequencing of the CcpA protein, and graduate student $\mathrm{H}$. Fukuda, and undergraduate students Y. Okamoto and T. Suji, for their help in the experiments.

\section{REFERENCES}

Botsford, J. L. \& Harman, J. G. (1992). Cyclic AMP in prokaryotes. Microbiol Rev 56, 100-122.

Chambliss, G. H. (1993). Carbon source-mediated catabolite repression. In Bacillus subtilis, pp. 213-219. Edited by A. L. Sonenshein, J. A. Hoch \& R. Losick. Washington, DC: American Society for Microbiology.

Chang, A. C. Y. \& Cohen, S. N. (1978). Construction and characterization of amplifiable multicopy DNA cloning vehicles derived from the P15A cryptic miniplasmid. J Bacteriol 134, 1141-1156.

Chasin, L. A. \& Magasanik, B. (1968). Induction and repression of the histidine-degrading enzymes of Bacillus subtilis. J Biol Chem 243, 5165-5178.

Fujita, Y. \& Freese, E. (1981). Isolation and properties of a Bacillus subtilis mutant unable to produce fructose-bisphosphatase. $J$ Bacteriol 145, 760-767.
Fujita, Y. \& Fujita, T. (1986): Identification and nucleotide sequence of the promoter region of the Bacillus subtilis gluconate operon. Nucleic Acids Res 14, 1237-1252.

Fujita, Y. \& Fujita, T. (1987). The gluconate operon gnt of Bacillus subtilis encodes its own transcriptional negative regulator. Proc Natl Acad Sci US A 84, 4524-4528.

Fujita, Y. \& Fujita, T. (1989). Effect of mutations causing gluconate kinase or gluconate permease deficiency on expression of the Bacillus subtilis gnt operon. J Bacteriol 171, 1751-1754.

Fujita, Y. \& Miwa, Y. (1994). Catabolite repression of the Bacillus subtilis gnt operon mediated by the CcpA protein. $J$ Bacteriol 176, 511-513.

Grundy, F. J., Waters, D. A., George Allen, S. H. \& Henkin, T. M. (1993). Regulation of the Bacillus subtilis acetate kinase gene by CcpA. J Bacteriol 175, 7348-7355.

Henkin, T. M., Grundy, F. J., Nicholson, W. L. \& Chambliss, G. H. (1991). Catabolite repression of $\alpha$-amylase gene expression in Bacillus subtilis involves a trans-acting gene product homologous to the Escherichia coli lacI and galR. Mol Microbiol 5, 575-584.

Horecker, B. L. (1974). D-Xylulose and D-xylose determination with D-xylose isomerase. In Methods of Enzymatic Analysis, 2nd English edn, pp. 1371-1376. Edited by H. U. Bergmeyer. New York: Academic Press.

Horwitz, S. B. \& Kaplan, N. O. (1964). Hexitol dehydrogenase of Bacillus subtilis. J Biol Chem 239, 830-838.

Jacob, S., Allmansberger, R., Gärtner, D. \& Hillen, W. (1991). Catabolite repression of the operon for xylose utilization from Bacillus subtilis W23 is mediated at the level of transcription and depends on a cis site in the $x y l A$ reading frame. Mol \& Gen Genet 229, 189-196

Krüger, S., Stülke, J. \& Hecker, M. (1993). Catabolite repression of $\beta$-glucanase synthesis in Bacillus subtilis. $J$ Gen Microbiol 139, 2047-2054.

Laemmli, U. K. (1970). Cleavage of structural proteins during the assembly of the head of bacteriophage T4. Nature 227, 680-685.

Martin, I., Debarbouille, M., Klier, A. \& Rapoport, G. (1989). Induction and metabolic regulation of levanase synthesis in Bacillus subtilis. J Bacteriol 171, 1885-1892.

Miwa, Y. \& Fujita, Y. (1987). Efficient utilization and operation of the gluconate-inducible system of the promoter of the Bacillus subtilis gnt operon in Escherichia coli. J Bacteriol 169, 5333-5335.

Miwa, Y. \& Fujita, Y. (1988). Purification and characterization of a repressor for the Bacillus subtilis gnt operon. J Biol Chem 263 , 13252-13257.

Miwa, Y. \& Fujita, Y. (1990). Determination of the cis sequence involved in catabolite repression of the Bacillus subtilis gnt operon; implication of a consensus sequence in catabolite repression in the genus Bacillus. Nucleic Acids Res 18, 7049-7053.

Miwa, Y. \& Fujita, Y. (1993). Promoter-independent catabolite repression of the Bacillus subtilis gnt operon. J Biocbem 113, 665-671.

Nicholson, W. L., Park, Y.-K., Henkin, T. M., Won, M., Weickert, M. J., Gaskell, J. A. \& Chambliss, G. H. (1987). Catabolite repression-resistant mutations of the Bacillus subtilis alpha-amylase promoter affect transcription levels and are in an operator-like sequence. $J$ Mol Biol 198, 609-618.

Nihashi, J. \& Fujita, Y. (1984). Catabolite repression of inositol dehydrogenase and gluconate kinase syntheses in Bacillus subtilis. Biochim Biopbys Acta 798, 88-95.

Oda, M., Katagiri, T., Tomura, D., Shoun, H., Hoshino, T. \& Furukawa, K. (1992). Analysis of the transcriptional activity of the but promoter in Bacillus subtilis and identification of a cis-acting 
regulatory region associated with catabolite repression downstream from the site of transcription. Mol Microbiol 6, 2573--2582.

Sanger, F., Nicklen, S. \& Coulson, A. R. (1977). DNA sequencing with chain-terminating inhibitors. Proc Natl Acad Sci USA 74, 5463 -5467.

Shaw, W. V. (1975). Chloramphenicol acetyltransferase from chloramphenicol-resistant bacteria. Methods Envymol 43, 737-755.

Weickert, M. J. \& Chambliss, G. H. (1990). Site-directed mutagenesis of a catabolite repression operator sequence in Bacillus subtilis. Proc Natl Acad Sci USA 87, 6238-6242.
Yoshida, K., Fujita, Y. \& Sarai, A. (1993). Missense mutations in the Bacillus subtilis gnt repressor that diminish operator binding ability. J Mol Biol 231, 167-174.

Zahler, S. A., Najimudin, N., Kessler, D. S. \& Vandeyar, M. A. (1990). $\alpha$-Acetolactate synthesis by Bacillus subtilis. In Biosynthesis of Branched Chain Amino Acids, pp. 309-329. Edited by Z. Barak, D. M. Chipman \& J. V. Schloss. Weinheim: VCH Verlagsgesellschaft.

Received 12 January 1994; revised 4 May 1994; accepted 11 May 1994. 